J. Clin. Chem. Clin. Biochem.

Vol. 26, 1988, pp. $863-871$

(C) 1988 Walter de Gruyter \& Co.

Berlin - New York

\title{
Nine Rheumatoid Factor Assays Compared
}

\author{
By J. P. M. M. Jaspers
}

Department of Clinical Chemistry, Het Nieuve Spittaal, Warnsveld, The Netherlands

\author{
R. J. M. Van Oers and B. Leerkes
}

Department of Clinical Chemistry, Ziekenhuiscentrum Apeldoorn, Juliana Ziekenhuis, Apeldoorn, The Netherlands

(Received April 18/October 3, 1988)

Summary: In this study we have investigated five quantitative and three semi-quantitative rheumatoid factor assays and the Rose-Waaler assay in 120 patients suffering from rheumatoid arthritis and in 76 with other systemic diseases. All tests measure the IgM anti-IgG antibodies.

The correlations between the quantitative tests were all higher than 0.86 and much better than between the quantitative and semi-quantitative tests and the semi-quantitative tests themselves ( $r$ between 0.22 and 0.85 ). The within run and between run precision studies for the quantitative tests showed CV values lower than $16 \%$.

In spite of the standardisation on the WHO and the Center of Disease Control Reference Preparation we found important differences in patient results.

From an analytical point of view, the quantitative assays for rheumatoid factors show certain advantages over the traditional haemagglutination tests.

\section{Introduction}

The measurement of rheumatoid factors in patients with rheumatoid arthritis can provide information about the diagnosis, prognosis and response to therapy of the disease.

The rheumatoid factors are autoantibodies against the Fc fragment of the immunoglobulin G (IgG).

The antibodies measured in most laboratory assays are of the IgM class, although they also appear in other immunoglobulin classes (1).

The classical method for the determination of the rheumatoid factors is the Rose-Waaler haemagglutination asșay $(2,3)$.

This semi-quantitative dilution assay is difficult to standardize, has a poor reproducibility and is rather laborious.
To overcome some of these problems, we have used for several years a modified Rose-Waaler assay in our laboratories (4).

Recently several new automated analysers and techniques for the quantitative determination of rheumatoid factors have become available.

They consist of radio-(5) and enzyme-immunoassays (6), or nephelometric (7) and turbidimetric methods $(8,9)$.

In this study we describe an evaluation of five quantitative rheumatoid factor assays, one semi-quantitative latex test and two modified Rose-Waaler assays. These tests all measure the IgM anti-IgG antibodies.

The results are compared with those determined with the traditional Rose-Waaler method. 


\section{Materials and Methods}

\section{(Semi-)quantitative rheumatoid factor tests}

The classical Rose-Waaler assay was carricd out by the Central Laboratory of the Blood Transfusion Service of the Dutch Red Cross, at Amsterdam. All other tests were carried out by us according to the protocols of the manufacturers.

The tests are:

Quantitative assays (A-E):

A: Beckman Array (Beckman Instruments, Inc, Brea, CA, USA).

B: Beckman ICS (Beckman Instruments, Inc, Brea, CA, USA).

C: Behring BNA (Behringwerke AG, Marburg, Federal Republic of Germany).

D: Diesse TasoMatic (Diesse, Monteriggioni (Si), Italy).

E: Hoffmann-LaRoche Cobas-Bio (Hoffmann-LaRoche, Basle, Switzerland)/Orion (Orion Diagnostica, Espoo, Finland).

Semi-quantitative assajs $(\mathrm{F}-\mathrm{I})$ :

F: Cellognost-RF-micro (Behringwerke AG, Marburg, Federal Republic of Germany).

G: RAHA (Fujirebio Inc, Tokyo, Japan).

H: RF-tube test (Hoffman-LaRoche, Basle, Switzerland).

I: Rose-Waaler.

The main characteristics of the nine rheumatoid factor tests and the instruments involved are shown in table 1 . We have classified the Diesse TasoMatic (D) under the quantitative methods although this instrument gives its results in a stepwise manner: $<50,50,60,70$ to 200 by steps of $10 \mathrm{IU} / \mathrm{ml}, 225$, 250,300 and $>350 \mathrm{IU} / \mathrm{ml}$.

\section{Patient samples}

The samples were obtained from patients visiting the rheumatology and pulmonary departments of our hospitals (tab. 2).

The diagnosis, rheumatoid arthritis, was obtained by the rheumatologists using the American Rheumatism Association criteria (10).

.

The blood samples were collected by venepuncture in vacutainer SST tubes (Becton and Dickinson, Rutherford, NJ, USA) and allowed to clot. The serum was removed and, in order to avoid repeated freezing and thawing, divided into aliquots and stored at $-20^{\circ} \mathrm{C}$ until assay.

All samples were inactivated by incubating for 30 minutes at $56^{\circ} \mathrm{C}$, except for the method of Diesse Taso-Matic (D) and the RF-tube test (H).

For both Beckman methods, Array (A) and ICS (B), the inactivated samples were centrifuged at $8000 \mathrm{~g}$ for five minutes.

\section{Standardisation and controls}

For the titration methods the "Relares serum" (the Dutch reference serum preparation for rheumatoid factors related to the "international reference preparation of rheumatoid arthritis serum of the WHO") (11) was used as a standard to convert titres to $\mathrm{IU} / \mathrm{ml}$.

For the preparation of this "Relares serum", plasma was first obtained by plasmapheresis from 20 patients with rheumatoid arthritis. Serum was then prepared by recalcification and di-

Tab. 1. Main characteristics of the nine (semi-)quantitative tests used for the rheumatoid factor assays. $\mathrm{CDC}=$ Center of Disease Control.

\begin{tabular}{|c|c|c|c|c|c|}
\hline Method & $\begin{array}{l}\text { Instruments, } \\
\text { principles and } \\
\text { reagents }\end{array}$ & $\begin{array}{l}\text { Standard } \\
\text { related } \\
\text { to }\end{array}$ & $\begin{array}{l}\text { Reference } \\
\text { values } \\
(\mathrm{IU} / \mathrm{ml})\end{array}$ & $\begin{array}{l}\text { Measuring } \\
\text { range } \\
(\mathrm{IU} / \mathrm{ml})\end{array}$ & \\
\hline A & $\begin{array}{l}\text { Beckman Array } \\
\text { Rate nephelometry } \\
\text { Rheumatoid factor reagent }\end{array}$ & $\mathrm{CDC}$ & $<60$ & $60-2350$ & \\
\hline B & $\begin{array}{l}\text { Beckman ICS } \\
\text { Rate nephelometry } \\
\text { Rheumatoid factor reagent }\end{array}$ & $\mathrm{CDC}$ & $<60$ & $60-400$ & \\
\hline $\mathrm{C}$ & $\begin{array}{l}\text { Behring BNA } \\
\text { Endpoint nephelometry } \\
\text { NA latex-RF reagent }\end{array}$ & WHO & $<17$ & $17-3540$ & \\
\hline D & $\begin{array}{l}\text { Diesse TasoMatic } \\
\text { Latex turbidimetry } \\
\text { Ra-tec reagent }\end{array}$ & WHO & $<50$ & $50-350$ & \\
\hline $\mathrm{E}$ & $\begin{array}{l}\text { Hoffmann-LaRoche Cobas-Bio } \\
\text { Immuno-turbidimetry } \\
\text { Orion reagents for } \\
\text { Rheumatoid Factors }\end{array}$ & WHO & $<15$ & $15-100$ & \\
\hline $\mathrm{F}$ & $\begin{array}{l}\text { Cellognost-RF-micro } \\
\text { Haemagglutination dilution } \\
\text { (modified Rose-Waaler) }\end{array}$ & Relares & $<50$ & - & \\
\hline$G$ & $\begin{array}{l}\text { RAHA } \\
\text { Haemagglutination dilution } \\
\text { (modified Rose-Waaler) }\end{array}$ & Relares & $<10$ & - & \\
\hline $\mathrm{H}$ & $\begin{array}{l}\text { RF-tube test } \\
\text { Direct latex-agglutination } \\
\text { dilution }\end{array}$ & Relares & $<25$ & - & \\
\hline I & $\begin{array}{l}\text { Rose-Waaler } \\
\text { Haemagglutination dilution }\end{array}$ & Relares & $<12.5$ & - &.$i$ \\
\hline
\end{tabular}


Tab. 2. The origin of the 196 patient samples.

\begin{tabular}{lc}
\hline Clinical diagnosis & Number \\
\hline 1. Classical rheumatoid arthritis & 95 \\
2. Definitive rheumatoid arthritis & 25 \\
3. Ankylosing spondylitis & 58 \\
4. Morbus Reiter & 5 \\
5. Reactive arthritis & 2 \\
6. Systemic lupus erythematosus & 4 \\
7. Sarcoidosis & 7 \\
\hline Total number & 196 \\
\hline
\end{tabular}

vided into ampoules and lyophilized. After reconstitution with $1 \mathrm{ml}$ distilled water the values were determined by Relares (Reference Laboratory Reuma-serology) by comparison with the WHO reference serum of $100 \mathrm{IU} / \mathrm{ml}$. The "Relares serum" gave a value of $400 \mathrm{IU} / \mathrm{ml}$ in the Rose-Waaler test and $200 \mathrm{IU} /$ $\mathrm{ml}$ in the Latex-tests.

For the five quantitative methods the standard(s) provided with the kits were used. The standard used for the Behring BNA (C), Diesse TasoMatic (D) and Cobas-Bio/Orion (E) is related to the WHO reference serum. For Beckman Array (A) and Beckman ICS (B) the standard is related to the "American Center of Disease Control National Reference Preparation for rheumatoid factors" (12).

In all semi-quantitative and quantitative assays we used the "Behring Rheumatoid Reference Serum" as a control.

This reference serum consists of a pool of human sera with a high concentration of rheumatoid factors. The reference serum is calibrated according to the Rose-Waaler test as recommended by the WHO (11) by comparison with the WHO International Reference Preparation.

In the quantitative tests we used also the "Relares serum" as a control serum.

\section{Statistical analysis}

Orthogonal regression analysis was performed according to the method of Deming as discussed by Cornbleet et al. (13).

The outlayers test described herein was only used in the correlation analyses of the five quantitative tests $(A-E)$. Outlayers were defined as values outside four times the standard error of estimate (13).

\section{Precision between and within runs}

Precision studies were performed with the following five quantitative methods: Beckman Array (A), Beckman ICS (B), Behring BNA (C), Diesse TasoMatic (D) and Cobas-Bio/Orion (E).

The within run precision analyses were carried out in pooled patient sera. Each serum was estimated 8 to 12 times. The sera were choosen so that the concentrations of rheumatoid factors were spread over the whole measuring range of the instruments. The value of $499 \mathrm{IU} / \mathrm{ml}$ by the Diesse TasoMatic method (D) however was obtained with diluted $(9 \mathrm{~g} / \mathrm{l} \mathrm{NaCl})$ serum.

For the between run precision analyses we used two to four samples in every run. These samples were Behring Rheumatoid Reference Serum for rheumatoid factors, Relares serum, Pooled Patient Serum, Standard $100 \mathrm{IU} / \mathrm{ml}$ of Diesse and Calibration Serum of Beckman.

\section{Correlation studies}

The titres of the dilution methods were converted to $\mathrm{IU} / \mathrm{ml}$ before the regression analyses were performed.
For the correlation studies we used the results of all $196 \mathrm{pa}$ tients, unless one or both values were zero, below the lowest standard or below the detection limit of the method.

Sensitivity, specificity and predictive value (14)

Sensitivity indicates the probability of positive test restults when the disease is present (positivity in disease).

It may be expressed by the following relationship:

Sensitivity $=\frac{\text { number of RA-patients with positive test }}{\text { total number of RA-patients }}$

Specificity indicates the probability of negative test results when the disease is not present (negativity in health).

It may be expressed by the following relationship:

Specificity $=\frac{\text { number of patients without RA with negative test }}{\text { total number of patients without RA }}$

The predictive value of a positive test is expressed by:

number of RA-patients with positive test

total number of positive tests

The predictive value of negative test is expressed by:

number of patients without RA with negative test

$$
\text { total number of negative tests }
$$

The predictive value of a positive (negative) test indicates the probability that the disease (RA, rheumatoid arthritis) is present (absent) when the test is positive (negative).

\section{Results and Discussion}

\section{Precision within and between runs}

The within and between run precision data are given in table 3.

The within run precision was good $(<4 \%)$ for the Beckman Array (A) method, the Behring BNA (B) method (except for the value $575 \mathrm{IU} / \mathrm{ml}$ ) and the Cobas-Bio/Orion (E) method [except near its detection limit of $15 \mathrm{IU} / \mathrm{ml}(\mathrm{CV}=16 \%$ for the value of $19 \mathrm{IU} / \mathrm{ml})]$.

The coefficient of variation of $8.4 \%$ for the Behring BNA (B) method was obtained in a pooled patient serum with a mean value of $575 \mathrm{IU} / \mathrm{ml}$. This value is near the beginning of the range requiring dilution of the sample.

The ten results for this pooled serum are shown in table 4 . The mean value for the four undiluted samples was $517 \mathrm{IU} / \mathrm{ml}$ and for the six automatically diluted samples $614 \mathrm{IU} / \mathrm{ml}$. This difference in mean values might be explained by the use of different parts of the calibration curve.

For the Diesse TasoMatic (D) the within run precision appeared to be satisfactory with a $\mathrm{CV}<11 \%$, taking into account the stepwise presentation of the results. 
Tab. 3. Precision between and within run (CV\%) of the Beckman Array (A), Beckman ICS (B), Behring BNA (C), Cobas-Bio/ Orion (D) and the Diesse TasoMatic (E).

All values are in $\mathrm{IU} / \mathrm{ml}$.

1 = Behring Rheumatoid Reference Serum. 2 = Relares Serum. 3 = For the Beckman Array (A) the Calibrator, for the Behring BNA (C) pooled serum and for the Diesse TasoMatic (E) the standard $100 \mathrm{IU} / \mathrm{l}$.

The columns 4 to 8 are pooled patient sera, covering the measuring range of the instruments.

\begin{tabular}{|c|c|c|c|c|c|c|c|c|c|}
\hline \multirow[t]{2}{*}{ Method } & & \multicolumn{3}{|c|}{ Between-run CV } & \multicolumn{3}{|c|}{ Within-run CV } & \multicolumn{2}{|l|}{$\therefore$} \\
\hline & & 1 & 2 & 3 & 4 & 5 & 6 & 7 & 8 \\
\hline $\begin{array}{l}\text { Beckman } \\
\text { Array } \\
\text { (A) }\end{array}$ & $\begin{array}{l}n \\
\text { Mean } \\
\text { CV\% }\end{array}$ & $\begin{array}{r}9 \\
146 \\
1.6\end{array}$ & $\begin{array}{c}10 \\
501 \\
4.0\end{array}$ & $\begin{array}{c}9 \\
215 \\
0.7\end{array}$ & $\begin{array}{c}10 \\
76 \\
3.1\end{array}$ & $\begin{array}{c}10 \\
81 \\
3.1\end{array}$ & $\begin{array}{c}10 \\
145 \\
0.7\end{array}$ & $\begin{array}{r}10 \\
256 \\
0.8\end{array}$ & $\begin{array}{c}10 \\
337 \\
0.9\end{array}$ \\
\hline $\begin{array}{l}\text { Beckman } \\
\text { ICS } \\
\text { (B) }\end{array}$ & $\begin{array}{l}\text { n } \\
\text { Mean } \\
\text { CV\% }\end{array}$ & $\begin{array}{c}19 \\
144 \\
12.3\end{array}$ & $\begin{array}{c}17 \\
544 \\
7.1\end{array}$ & $\begin{array}{l}- \\
-\end{array}$ & $\begin{array}{l}- \\
-\end{array}$ & $\begin{array}{l}- \\
-\end{array}$ & $\begin{array}{l}- \\
-\end{array}$ & $\begin{array}{l}- \\
-\end{array}$ & $\begin{array}{l}- \\
-\end{array}$ \\
\hline $\begin{array}{l}\text { Behring } \\
\text { BNA } \\
\text { (C) }\end{array}$ & $\begin{array}{l}\mathrm{n} \\
\text { Mean } \\
\mathrm{CV} \%\end{array}$ & $\begin{array}{c}8 \\
118 \\
8.8\end{array}$ & $\begin{array}{c}10 \\
280 \\
5.8\end{array}$ & $\begin{array}{c}19 \\
47 \\
5.5\end{array}$ & $\begin{array}{l}10 \\
97 \\
3.6\end{array}$ & $\begin{array}{r}10 \\
575 \\
8.4\end{array}$ & $\begin{array}{r}10 \\
1938 \\
4.0\end{array}$ & $\begin{array}{l}- \\
-\end{array}$ & $\begin{array}{l}- \\
-\end{array}$ \\
\hline $\begin{array}{l}\text { Cobas- } \\
\text { Bio/ } \\
\text { Orion (D) }\end{array}$ & $\begin{array}{l}\mathrm{n} \\
\text { Mean } \\
\text { CV\% }\end{array}$ & $\begin{array}{l}16 \\
76 \\
11.6\end{array}$ & $\begin{array}{r}16 \\
208 \\
2.8\end{array}$ & $\begin{array}{l}- \\
-\end{array}$ & $\begin{array}{l}11 \\
19 \\
16.0\end{array}$ & $\begin{array}{l}12 \\
25 \\
2.7\end{array}$ & $\begin{array}{c}12 \\
38 \\
0.8\end{array}$ & $\begin{array}{c}10 \\
73 \\
0.8\end{array}$ & $\begin{array}{c}10 \\
103 \\
0.9\end{array}$ \\
\hline $\begin{array}{l}\text { Diesse } \\
\text { Taso- } \\
\text { Matic (E) }\end{array}$ & $\begin{array}{l}\text { n } \\
\text { Mean } \\
\text { CV\% }\end{array}$ & $\begin{array}{l}39 \\
90 \\
11.1\end{array}$ & $\begin{array}{c}36 \\
226 \\
16.7\end{array}$ & $\begin{array}{c}43 \\
105 \\
14.8\end{array}$ & $\begin{array}{c}9 \\
76 \\
7.0\end{array}$ & $\begin{array}{c}9 \\
126 \\
11.2\end{array}$ & $\begin{array}{c}9 \\
160 \\
6.1\end{array}$ & $\begin{array}{c}9 \\
198 \\
10.9\end{array}$ & $\begin{array}{r}8 \\
499 \\
6.9\end{array}$ \\
\hline
\end{tabular}

Tab. 4. Results of the within-run precision study of a pooled patient serum with a value around the automatic dilution step of the Behring BNA method (C). See text for further explanation.

\begin{tabular}{lcl}
\hline Sample & \multicolumn{2}{l}{ Results in $\mathrm{IU} / \mathrm{ml}$} \\
\cline { 2 - 3 } & Undiluted & Diluted \\
\hline 1 & $>528$ & 619 \\
2 & 523 & - \\
3 & 503 & - \\
4 & 518 & - \\
5 & $>528$ & 631 \\
6 & $>528$ & 609 \\
7 & $>528$ & 602 \\
8 & $>528$ & 601 \\
9 & $>528$ & 621 \\
10 & 524 & - \\
\hline Mean & 517 & 614 \\
\hline
\end{tabular}

The between run precision for the Beckman Array (A) and the Behring BNA (C) was good $(<9 \%)$, for the other quantitative methods acceptable $(<17 \%)$.

The manual titre methods gave a maximal difference of only one dilution step.

\section{Correlation studies}

The correlations between the quantitative and semiquantitative methods and between the semi-quantitative methods themselves are shown in table 5.
It can be seen that the coefficients of correlation ( $r$ ) between the quantitative methods $\mathrm{A}-\mathrm{E}$ and the semiquantitative tests $\mathrm{F}$ and $\mathrm{I}$ are all below or equal to 0.53 . Between the quantitative methods $\mathrm{A}-\mathrm{E}$ and the RAHA (G) and RF-tube test $(\mathrm{H})$ a higher correlation was observed, i.e. $r=0.65$ to $r=0.85$.

The coefficients of correlation between each of the semi-quantitative methods (F, G, H and I) were all less than 0.65 .

In table 6 the coefficients of correlation between each of the five quantitative tests $(\mathrm{A}, \mathrm{B}, \mathrm{C}, \mathrm{D}$ and $\mathrm{E})$ are shown, ranging from $r=0.86$ to $r=0.99$.

In figures 1 and 2 the serum values obtained with the five quantitative methods $\mathrm{A}-\mathrm{E}$ are plotted against each other.

The correlation between the quantitative tests themselves is much stronger then between the semi-quantitative and quantitative tests or between the semiquantitative tests themselves.

This less satisfactory coefficient of correlation can be partly explained by the use of titres. In the conversion of titres to numerical values $(\mathrm{IU} / \mathrm{ml})$ a difference of only one dilution step causes the doubling or halving of the value in $\mathrm{IU} / \mathrm{ml}$ (15). 
Tab. 5. Deming debiased regression analyses between the quantitative $(A-E)$ and the semi-quantitative methods $(F-I)$ and the semi-quantitative tests. $(F-I)$ themselves.

No correction for outlayers was applied here.

$\mathrm{n}=$ number of patients; $\mathrm{r}=$ coefficient of correlation; $\mathrm{b}=$ intercept; $\mathrm{a}=$ slope; $\mathrm{y}=\mathrm{b}+\mathrm{ax}$.

(Vertical method $=\mathrm{x}$; horizontal method $=\mathrm{y}$ ).

\begin{tabular}{|c|c|c|c|c|c|}
\hline Method & & $\begin{array}{l}\text { Cellognost- } \\
\text { RF-micro } \\
\text { (F) }\end{array}$ & $\begin{array}{l}\text { RAHA } \\
\text { (G) }\end{array}$ & $\begin{array}{l}\text { RF-tube } \\
\text { test } \\
(\mathrm{H})\end{array}$ & $\begin{array}{l}\text { Rose- } \\
\text { Waaler } \\
\text { (I) }\end{array}$ \\
\hline $\begin{array}{l}\text { Beckman } \\
\text { Array } \\
\text { (A) }\end{array}$ & $\begin{array}{l}n \\
r \\
b \\
a\end{array}$ & $\begin{array}{r}50 \\
0.22 \\
-131 \\
0.71\end{array}$ & $\begin{array}{r}65 \\
0.70 \\
89 \\
0.50\end{array}$ & $\begin{array}{r}72 \\
0.72 \\
27 \\
0.28\end{array}$ & $\begin{array}{r}61 \\
0.28 \\
40 \\
0.82\end{array}$ \\
\hline $\begin{array}{l}\text { Beckman } \\
\text { ICS } \\
\text { (B) }\end{array}$ & $\begin{array}{l}n \\
r \\
b \\
a\end{array}$ & $\begin{array}{r}56 \\
0.33 \\
-150 \\
0.72\end{array}$ & $\begin{array}{r}78 \\
0.82 \\
47 \\
0.55\end{array}$ & $\begin{array}{r}87 \\
0.65 \\
-13 \\
0.37\end{array}$ & $\begin{array}{r}68 \\
0.46 \\
19 \\
0.82\end{array}$ \\
\hline $\begin{array}{l}\text { Behring } \\
\text { BNA } \\
\text { (C) }\end{array}$ & $\begin{array}{l}\mathrm{n} \\
\mathrm{r} \\
\mathrm{b} \\
\mathrm{a}\end{array}$ & $\begin{array}{r}55 \\
0.50 \\
-230 \\
1.42\end{array}$ & $\begin{array}{r}75 \\
0.78 \\
19 \\
1.06\end{array}$ & $\begin{array}{r}88 \\
0.81 \\
-32 \\
0.72\end{array}$ & $\begin{array}{r}68 \\
0.53 \\
-46 \\
1.60\end{array}$ \\
\hline $\begin{array}{l}\text { Diesse } \\
\text { TasoMatic } \\
\text { (D) }\end{array}$ & $\begin{array}{l}n \\
r \\
b \\
a\end{array}$ & $\begin{array}{r}47 \\
0.47 \\
-429 \\
2.99\end{array}$ & $\begin{array}{r}56 \\
0.76 \\
-94 \\
2.14\end{array}$ & $\begin{array}{r}59 \\
0.85 \\
-119 \\
1.49\end{array}$ & $\begin{array}{r}55 \\
0.47 \\
-204 \\
3.10\end{array}$ \\
\hline $\begin{array}{l}\text { Cobas- } \\
\text { Bio/ } \\
\text { Orion } \\
\text { (E) }\end{array}$ & $\begin{array}{l}\mathbf{n} \\
\mathrm{r} \\
\mathrm{b} \\
\mathrm{a}\end{array}$ & $\begin{array}{r}54 \\
0.41 \\
-294 \\
2.05\end{array}$ & $\begin{array}{r}72 \\
0.75 \\
-21 \\
1.51\end{array}$ & $\begin{array}{r}85 \\
0.84 \\
-58 \\
1.01\end{array}$ & $\begin{array}{r}64 \\
0.46 \\
-110 \\
2.28\end{array}$ \\
\hline $\begin{array}{l}\text { Cellognost } \\
\text { RF-micro } \\
\text { (F) }\end{array}$ & $\begin{array}{l}n \\
r \\
b \\
a\end{array}$ & $\begin{array}{l}- \\
- \\
-\end{array}$ & $\begin{array}{r}53 \\
0.57 \\
192 \\
0.74\end{array}$ & $\begin{array}{r}55 \\
0.45 \\
60 \\
0.52\end{array}$ & $\begin{array}{r}55 \\
0.45 \\
239 \\
1.09\end{array}$ \\
\hline $\begin{array}{l}\text { RAHA } \\
\text { (G) }\end{array}$ & $\begin{array}{l}n \\
r \\
b \\
a\end{array}$ & $\begin{array}{l}- \\
- \\
-\end{array}$ & $\begin{array}{l}- \\
- \\
-\end{array}$ & $\begin{array}{r}71 \\
0.64 \\
-55 \\
0.69\end{array}$ & $\begin{array}{r}61 \\
0.53 \\
-75 \\
1.49\end{array}$ \\
\hline $\begin{array}{l}\text { RF-tube } \\
\text { test } \\
\text { (H) }\end{array}$ & $\begin{array}{l}\mathbf{n} \\
\mathbf{r} \\
\mathbf{b} \\
\mathbf{a}\end{array}$ & $\begin{array}{l}- \\
- \\
-\end{array}$ & $\begin{array}{l}- \\
- \\
-\end{array}$ & $\begin{array}{l}- \\
- \\
-\end{array}$ & $\begin{array}{r}66 \\
0.46 \\
53 \\
2.18\end{array}$ \\
\hline
\end{tabular}

\section{Standardisation and controls}

\section{Semi-quantitative methods}

In order to convert titres to $\mathrm{IU} / \mathrm{ml}$ for each method in every run the Relares serum was assayed. After all assays were complete, the mean titre of the Relares serum was compared with its target value in $\mathrm{IU} / \mathrm{ml}$ (16).
Tab. 6. Deming debiased regression analyses between the five quantitative methods $(A-E)$ without outlayers.

$\mathrm{n}=$ number of patients; $\mathrm{r}=$ coefficient of correlation; $\mathrm{b}=$ intercept; $\mathrm{a}=$ slope; $\mathrm{y}=\mathrm{b}+\mathrm{ax}$.

(Vertical method $=x$, horizontal method $=y$ ). $\mathrm{e}=$ number of outlayers.

\begin{tabular}{|c|c|c|c|c|c|}
\hline Method & & $\begin{array}{l}\text { Beckman } \\
\text { ICS } \\
\text { (B) }\end{array}$ & $\begin{array}{l}\text { Behring } \\
\text { BNA } \\
\text { (C) }\end{array}$ & $\begin{array}{l}\text { Diesse } \\
\text { Taso- } \\
\text { Matic } \\
\text { (D) }\end{array}$ & $\begin{array}{l}\text { Cobas- } \\
\text { Bio/ } \\
\text { Orion } \\
\text { (E) }\end{array}$ \\
\hline $\begin{array}{l}\text { Beckman } \\
\text { Array } \\
\text { (A) }\end{array}$ & $\begin{array}{l}n \\
r \\
b \\
a \\
e\end{array}$ & $\begin{array}{r}59 \\
0.99 \\
38 \\
0.96 \\
17\end{array}$ & $\begin{array}{r}68 \\
0.95 \\
46 \\
0.50 \\
6\end{array}$ & $\begin{array}{r}56 \\
0.86 \\
86 \\
0.20 \\
1\end{array}$ & $\begin{array}{r}65 \\
0.98 \\
40 \\
0.34 \\
9\end{array}$ \\
\hline
\end{tabular}

\begin{tabular}{|c|c|c|c|c|c|}
\hline Beckman & $\mathbf{n}$ & - & 84 & 56 & 77 \\
\hline ICS & $r$ & - & 0.98 & 0.89 & 0.98 \\
\hline (B) & b & - & 26 & 52 & -7 \\
\hline & a & - & 0.75 & 0.30 & 0.56 \\
\hline & e & - & 15 & 4 & 12 \\
\hline Behring & $\mathbf{n}$ & - & - & 54 & 80 \\
\hline BNA & $\mathbf{r}$ & - & - & 0.97 & 0.98 \\
\hline (C) & b & - & - & 9 & 7 \\
\hline & a & - & - & 0.58 & 0.74 \\
\hline & $\dot{\mathrm{e}}$ & - & - & 6 & 8 \\
\hline Diesse & $\mathbf{n}$ & - & - & - & 53 \\
\hline TasoMatic & $r$ & - & - & - & 0.98 \\
\hline (D) & b & - & - & - & 2 \\
\hline & a & - & - & - & 1.20 \\
\hline & e & - & - & - & 5 \\
\hline
\end{tabular}

For the Cellognost-RF-micro (F), a titre of $1: 80$ corresponded to $400 \mathrm{IU} / \mathrm{ml}$, for the RAHA (G) a titre of $1: 2560$ represented $300 \mathrm{IU} / \mathrm{ml}$, while for the RFtube-test $(\mathrm{H})$ a titre of $1: 160$ represented a value of $200 \mathrm{IU} / \mathrm{ml}$. For the Rose-Waaler method (I) the Relares serum was used as a standard $(400 \mathrm{IU} / \mathrm{ml})$ in every run to convert the titres into $\mathrm{IU} / \mathrm{ml}$.

In every run also the Behring Rheumatoid Reference serum was assayed. For the Cellognost-RF-Micro (F) a value of $200 \mathrm{IU} / \mathrm{ml}$ was found, for the RAHA (G) $50 \mathrm{IU} / \mathrm{ml}$ and for the RF-tube test $(\mathrm{H}) 75 \mathrm{IU} / \mathrm{ml}$.

For the Rose-Waaler method this Behring Rheumatoid Reference Serum was assayed twice at $100 \mathrm{IU} /$ $\mathrm{ml}$.

\section{Quantitative methods}

Data were first obtained by using the standards supplied with the kits. In addition the Relares Serum and the Behring Rheumatoid Reference Serum were analysed in every run. Table 7 shows the mean values and standard deviations for these two sera. 

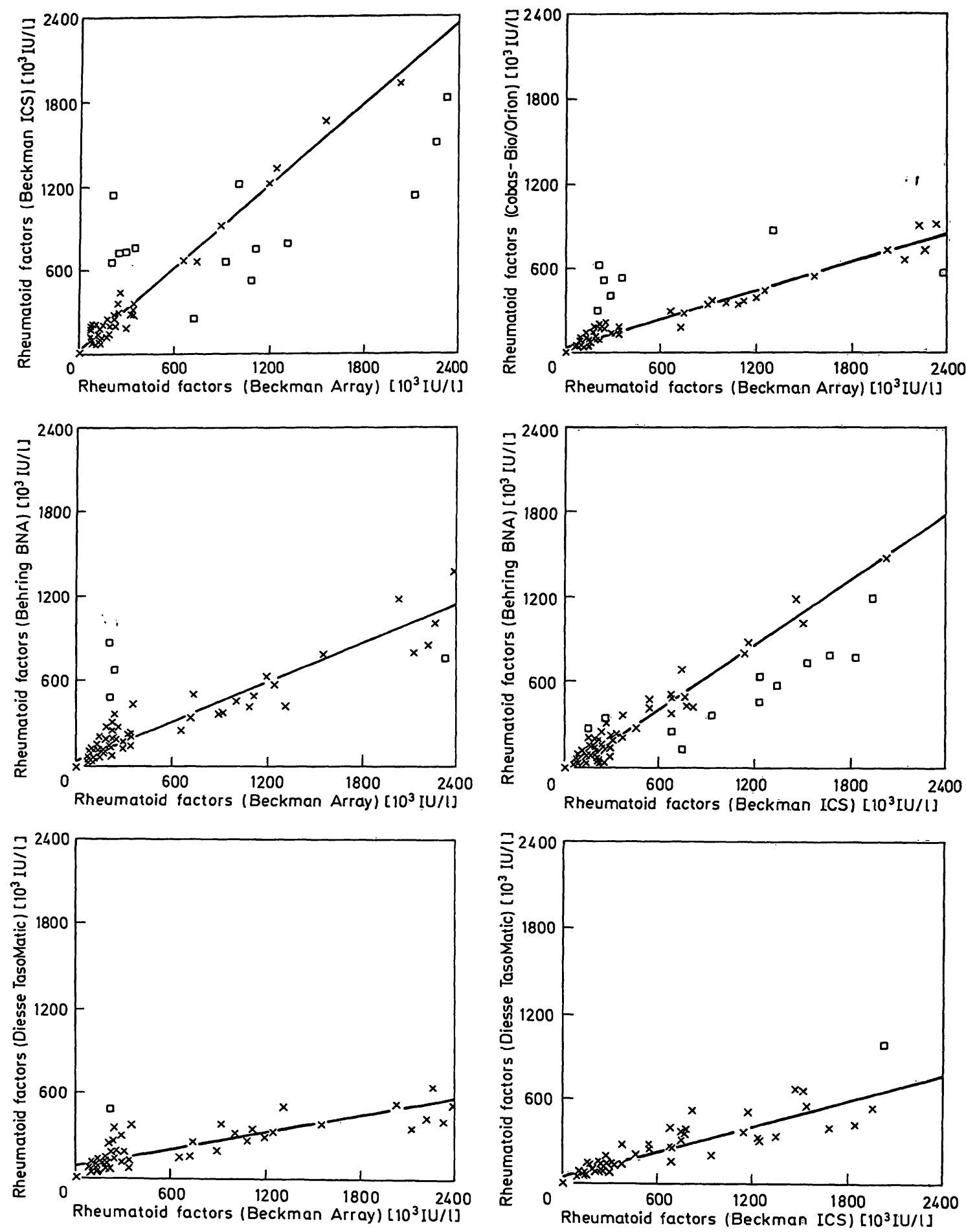

Fig. 1. Graphs showing the correlations between the quantitative rheumatoid factor assays.

All values are in IU $/ \mathrm{ml}$. $\square=$ outlayer in Deming debiased orthogonal regression analyses.

It should be mentioned that the standards used in methods A and B were related to the reference preparation of the Center of Disease Control, but for the other methods (C, D and E) to that of the WHO.

The value of the Center of Disease Control Reference Preparation is 2.3 times the value of the WHO (17).

Therefore in table 7, the values of "Relares" and "Behring" sera for methods A and B are also given in WHO units.
The values for the Relares serum obtained with the quantitative methods, all related to the WHO units, are now between 208 and $280 \mathrm{IU} / \mathrm{ml}$ and the values for the Behring Rheumatoid Reference Serum between 62 and $118 \mathrm{IU} / \mathrm{ml}$.

In spite of standardisation using the well defined WHO Reference Preparation for the quantitative tests $C, D$ and $E$ and using the Center of Disease Control Reference Preparation for the methods A and B, there 

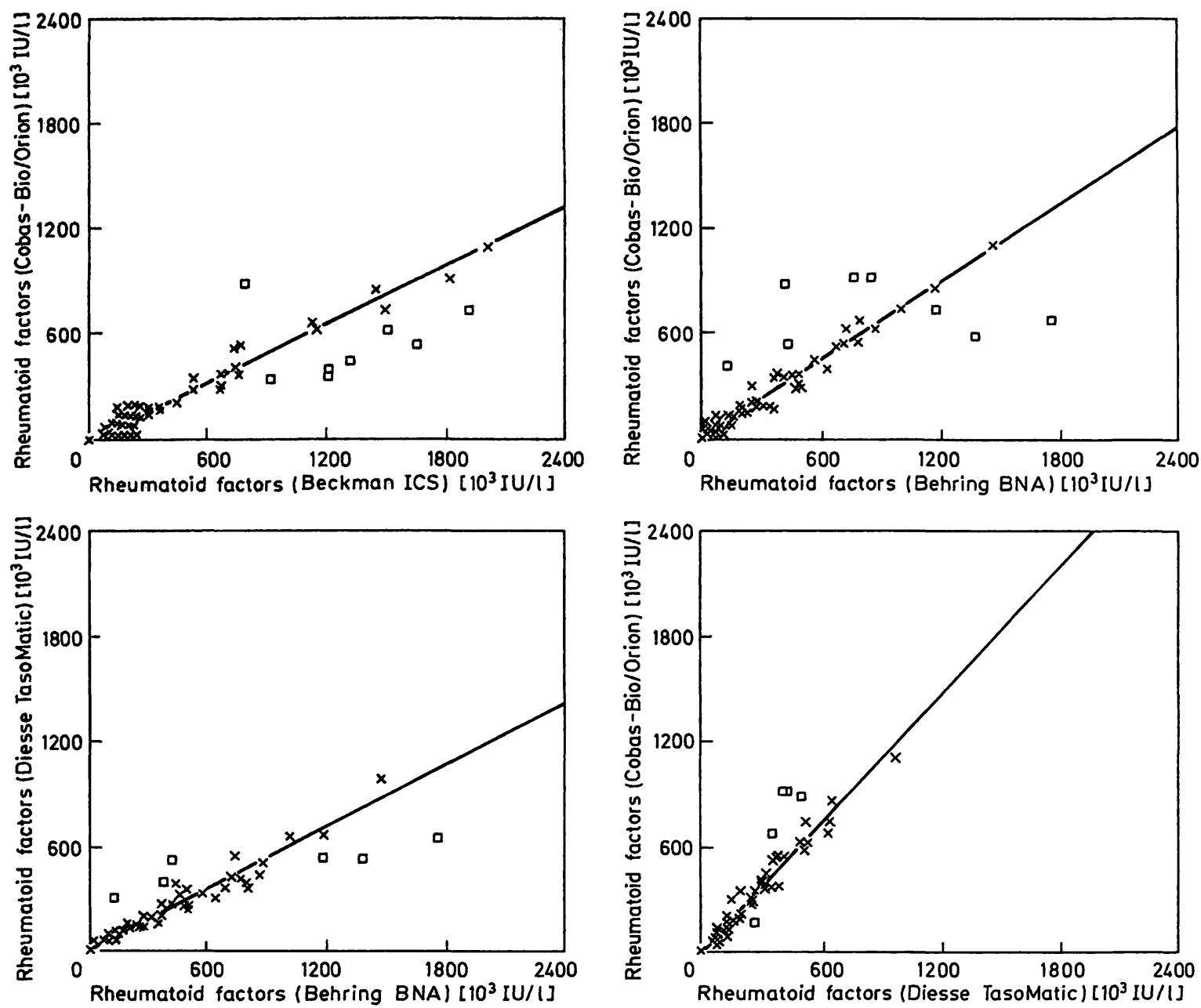

Fig. 2. Graphs showing the correlations between the quantitative rheumatoid factor assays.

All values are in $\mathrm{IU} / \mathrm{ml} . \square=$ outlayer in Deming debiased orthogonal regression analyses.

Tab. 7. Values of the Relares serum and Behring Rheumatoid Reference Serum related to the WHO units for methods $\mathrm{C}, \mathrm{D}$ and $\mathrm{E}$ and to the Center of Disease Control units for methods $A$ and $B$.

The values in the second column in brackets by methods $A$ and $B$ are obtained after conversion of the Center of Disease Control units to WHO units. (Here we used: Center of Disease Control $=2.3 \times$ WHO).

\begin{tabular}{|c|c|c|c|}
\hline Method & $\begin{array}{l}\text { Standard } \\
\text { related } \\
\text { to: }\end{array}$ & $\begin{array}{l}\text { "Relares" } \\
\text { mean and } \\
{[\mathrm{S} . \mathrm{D} .]} \\
\mathrm{IU} / \mathrm{ml}\end{array}$ & $\begin{array}{l}\text { "Behring" } \\
\text { mean and } \\
\text { [S.D.] } \\
\text { IU } / \mathrm{ml}\end{array}$ \\
\hline $\begin{array}{l}\text { Beckman } \\
\text { Array (A) }\end{array}$ & $\begin{array}{l}\text { CDC } \\
\text { (WHO) }\end{array}$ & $\begin{array}{l}501[20] \\
(218)\end{array}$ & $\begin{array}{l}146[2] \\
(63)\end{array}$ \\
\hline $\begin{array}{l}\text { Beckman } \\
\text { ICS (B) }\end{array}$ & $\begin{array}{l}\text { CDC } \\
\text { (WHO) }\end{array}$ & $\begin{array}{l}544[39] \\
(237)\end{array}$ & $\begin{array}{l}144[12] \\
(62)\end{array}$ \\
\hline $\begin{array}{l}\text { Behring } \\
\text { BNA (C) }\end{array}$ & WHO & 280 [16] & $118[10]$ \\
\hline $\begin{array}{l}\text { Diesse } \\
\text { TasoMatic (D) }\end{array}$ & WHO & $226[38]$ & 90 [10] \\
\hline $\begin{array}{l}\text { Cobas-Bio/ } \\
\text { Orion (E) }\end{array}$ & WHO & 208 [6] & $76[8]$ \\
\hline
\end{tabular}

was a large systematic difference in the actual values found. These differences were observed for the patient sera (tab. 6, figs. 1 and 2) as well as for the Relares Serum and the Behring Rheumatoid Reference Serum (tab. 7).

This discrepancy in bias might be explained by the variability of the IgG antibodies used in the various kits. Another explanation could be the difference in the origin of the rheumatoid factor preparations used as standards in the kits, since these rheumatoid factors are a group of diverse globulins.

We also investigated the number of positive patient sera which exceeded the measuring ranges of the kits. A large difference was found between the methods used; see table 8 .

Sera showing values above the upper limit of the measuring range were diluted $1: 6$. Further dilution was necessary for sixteen of the sera, but only for the Cobas-Bio/Orion method. 
Tab. 8. Proportions of patient sera reanalysed because values exceeded the measuring ranges of the various methods.

\begin{tabular}{lccc}
\hline Method & $\begin{array}{l}\text { Total positives } \\
\text { of the 196 } \\
\text { patient sera }\end{array}$ & \multicolumn{2}{c}{$\begin{array}{l}\text { Exceeding } \\
\text { measured range }\end{array}$} \\
\cline { 3 - 4 } & & $\mathrm{n}$ & $\%$ \\
\hline Beckman Array (A) & 80 & 3 & $4 \%$ \\
Beckman ICS (B) & 85 & 27 & $32 \%$ \\
Behring BNA (C) & 109 & 0 & $0 \%$ \\
Diesse TasoMatic (D) & 67 & 17 & $25 \%$ \\
Cobas-Bio/Orion (E) & 91 & 48 & $53 \%$ \\
\hline
\end{tabular}

In table 9 the sensitivity, specificity, the positive and the negative predictive values of the methods used $(A-I)$ are shown.

With regard to these calculations we divided the patients into two groups. The first group consisted of the patients suffering from classical rheumatoid arthritis and definitive rheumatoid arthritis, i.e. numbers one and two from table 2. The second group consisted of the patients suffering from other diseases, such as reactive arthritis, sarcoidosis, ankylosing spondylitis, Morbus Reiter and systemic lupus erythematosus, i. e. numbers three to seven from table 2.
Table 9 shows that of the semi-quantitative methods $(F-I)$, the RF-tube test $(H)$ gives the best results. The quantitative methods $(A-E)$ do not show identical results.

The clinical usefulness of the quantitative tests seems identical to, or better than the traditional Rose-Waaler method (I) or the other semi-quantitative tests (F, G and $\mathrm{H}$ ); see table 9. However, from the analytical point of view we recommend the use of one of the quantitative tests for the determination of the rheumatoid factors, with patient results expressed in IU/ $\mathrm{ml}$.

\section{Acknowledgement}

The authors wishes to thank Dr. H. L. J. M. Fleuren, clinical chemist at Kampen and Emmeloord for his critical remarks, and Dr. B. de Leeuw and S. H. Oei, rheumatologists of the Juliana Hospital and $D$. R. Siewertsz van Reesema, rheumatologist and $P$. B. Luursema and $R$. H. U. Rammeloo, pulmonologists of Het Nieuwe Spittaal for their kind cooperation.

The support by Beckman, Behring, VJT (Diesse) and HoffmanLaRoche is highly appreciated.

Tab. 9. Sensitivity, specificity and predictive values of positive and negative results of the various methods in "RA" and "no-RA" patients. See text for further explanation. $\mathrm{RA}=$ rheumatoid arthritis.

\begin{tabular}{|c|c|c|c|c|c|c|c|}
\hline \multirow[t]{2}{*}{ Method } & \multicolumn{3}{|c|}{$\begin{array}{l}\text { Patient } \\
\text { classification }\end{array}$} & \multirow{2}{*}{$\begin{array}{l}\text { Sensi- } \\
\text { tivity } \\
\%\end{array}$} & \multirow{2}{*}{$\begin{array}{l}\text { Speci- } \\
\text { ficity } \\
\%\end{array}$} & \multicolumn{2}{|c|}{ Predictive value of } \\
\hline & & Pos. & Neg. & & & $\begin{array}{l}\text { pos. test } \\
\%\end{array}$ & $\begin{array}{l}\text { neg. test } \\
\%\end{array}$ \\
\hline $\begin{array}{l}\text { Beckman } \\
\text { Array (A) }\end{array}$ & $\begin{array}{l}\text { RA } \\
\text { no-RA }\end{array}$ & $\begin{array}{r}74 \\
4\end{array}$ & $\begin{array}{l}34 \\
70\end{array}$ & 69 & 95 & 95 & 67 \\
\hline $\begin{array}{l}\text { Beckman } \\
\text { ICS (B) }\end{array}$ & $\begin{array}{l}\text { RA } \\
\text { no-RA }\end{array}$ & $\begin{array}{l}72 \\
10\end{array}$ & $\begin{array}{l}39 \\
64\end{array}$ & 65 & 86 & 88 & 62 \\
\hline $\begin{array}{l}\text { Behring } \\
\text { BNA (C) }\end{array}$ & $\begin{array}{l}\text { RA } \\
\text { no-RA }\end{array}$ & $\begin{array}{l}96 \\
11\end{array}$ & $\begin{array}{l}15 \\
61\end{array}$ & 86 & 85 & 90 & 80 \\
\hline $\begin{array}{l}\text { Diesse } \\
\text { TasoMatic (D) }\end{array}$ & $\begin{array}{l}\text { RA } \\
\text { no-RA }\end{array}$ & $\begin{array}{r}64 \\
2\end{array}$ & $\begin{array}{l}49 \\
72\end{array}$ & 57 & 97 & 97 & 60 \\
\hline $\begin{array}{l}\text { Cobas-Bio/ } \\
\text { Orion (E) }\end{array}$ & $\begin{array}{l}\mathrm{RA} \\
\text { no-RA }\end{array}$ & $\begin{array}{r}85 \\
6 \\
--\end{array}$ & $\begin{array}{r}27 \\
67 \\
--\end{array}$ & 76 & 92 & 93 & 71 \\
\hline $\begin{array}{l}\text { Cellognost } \\
\text { RF-micro (F) }\end{array}$ & $\begin{array}{l}\text { RA } \\
\text { no-RA }\end{array}$ & $\begin{array}{r}59 \\
2\end{array}$ & $\begin{array}{l}52 \\
72\end{array}$ & 53 & 97 & 97 & 58 \\
\hline $\begin{array}{l}\text { RAHA } \\
(G)\end{array}$ & $\begin{array}{l}\text { RA } \\
\text { no-RA }\end{array}$ & $\begin{array}{r}71 \\
6\end{array}$ & $\begin{array}{l}38 \\
68\end{array}$ & 65 & 92 & 92 & 54 \\
\hline $\begin{array}{l}\text { RF-tube } \\
\text { test }(\mathrm{H})\end{array}$ & $\begin{array}{l}\text { RA } \\
\text { no-RA }\end{array}$ & $\begin{array}{r}87 \\
3\end{array}$ & $\begin{array}{l}24 \\
71\end{array}$ & 78 & 96 & 97 & 75 \\
\hline $\begin{array}{l}\text { Rose-Waaler } \\
\text { (I) }\end{array}$ & $\begin{array}{l}\text { RA } \\
\text { no-RA }\end{array}$ & $\begin{array}{r}68 \\
2\end{array}$ & $\begin{array}{l}43 \\
72\end{array}$ & 61 & 97 & 97 & 63 \\
\hline
\end{tabular}




\section{References}

1. Egeland, T. \& Munthe, E. (1983) Clin. Rhcum. Dis. 9, $135-160$.

2. Waaler, E. (1940) Acta Pathol. Microbiol. Scand. 17, 172188.

3. Rose, H. M:, Ragan, C., Pearch, E. \& Olmstcad Lipman, E. (1948) Proc. Soc. Exp. Biol. Med. 68, 1-6.

4. Fleuren, H. L. J. M., Van Ocrs, R. J. M. \& Jaspers, J. P. M. M. (1983) Tijdschrift NVKC 4, 126-130.

5. Koopman, W. J. \& Schrohenloker, R. E. (1980) Arthritis Rheum. 23, 302-308.

6. Bampton, J. L. M., Cawston, T. E., Kyle, M. V. \& Hazeleman, B. L. (1985) Ann. Rbeum. Dis. 44, 13-19.

7. Roberts-Thomson, P. J., McEvoy, R., Langhans, T. \& Bradley, J. (1985) Ann. Rheum. Dis. 44, 379-383.

8. Melanies, L. M., Ruutsalo, H. M. \& Nissila, H. (1986) Clin. Chem. 32, 1890-1984.
9. Borque, L., Yago, M., Mar, C. \& Rodriques, C. (1986) Clin. Chem. 32, 124-129.

10. Committee of the American Rheumation Association. Revision of Diagnostic Criteria for Rheumatoid Arthritis (1959) Arth. Reum. 2, 16-20.

11. Anderson, S. G., Bentzon, M. W., Houba, V. \& Krag, P. (1970) Bull. Wld. Hith. Org. 42, 311-318.

12. Jones, W. L. \& Wiggins, G. L. (1973) Am. J. Clin. Pathol. $60,703-706$.

13. Cornbleet, P. J. \& Gochman, V. (1979) Clin. Chem. 25, $432-438$

14. Griner, P. F. (1981) Ann. Int. Med. 94, 553-600.

15. Ritchie, R. P., Publication ICS-15, Beckman Instruments International S. A., Switzerland.

16. Feltkamp, T. E. W. (1987) Report by Stichting Relares, Amsterdam.

17. Feltkamp, T. E. W. (1986) Unpubl. data.

J. P. M. M. Jaspers

Het Nieuwe Spittaal

Postbus 2002

NL-7230 GB Warnsveld 


$$
\therefore
$$

